Jan Kalendovsky (Brno, Czechy)

Tomasz Lissowski (Warszawa)

Krzysztof Tomasz Witc zak (Uniwersytet Łódzki)

\title{
Henryk Kahane - zapomniany mistrz szachowy
}

Henryk Kahane urodził się 15 czerwca 1906 r. w Tomaszowie Rawskim (Mazowieckim) i przy obrzezaniu otrzymał żydowskie imiona Hersz Calel ${ }^{1}$. Jednak $\mathrm{w}$ gronie rodzinnym i wśród przyjaciół powszechnie wołano nań „Heniek“ (wg ustnego świadectwa jego kuzynki pani Noemi Zofii Amely z domu Kahane). Edukację w zakresie szkoły średniej pobierał "Heniek“ w Miejskim Gimnazjum i Liceum Realnym Koedukacyjnym w Tomaszowie Mazowieckim. Po zdaniu matury (1926) wybrał on nietypowy sposób kontynuowania nauki, a mianowicie podjął studia politechniczne na kierunku chemicznym. Decyzja o rozpoczęciu studiów chemicznych zapewne wiązała się z powstaniem w 1911 r. w jego rodzinnym mieście Tomaszowskiej Fabryki Sztucznego Jedwabiu, największego $\mathrm{w}$ regionie zakładu pracy zatrudniającego w okresie dwudziestolecia międzywojennego kilka tysięcy pracowników. Studia chemiczne podjął jednak nie na polskiej uczelni, lecz za granicą. W 1927 r. „Heniek“ Kahane udał się do Brna, największego miasta Moraw,

\footnotetext{
${ }^{1}$ Archiwum Państwowe w Piotrkowie Trybunalskim, Akta stanu cywilnego okręgu bóżniczego w Tomaszowie Mazowieckim, akta urodzonych w latach 1905-1908, s. 62, akt urodzenia nr 99/1906: „Działo się w mieście Tomaszowie dziewiątego / dwudziestego drugiego czerwca 1906 roku o godzinie trzeciej po południu. Zjawił się Abram Jakub Kahane (Абрамъ Яковъ Каганъ), kupiec, lat 20, tutejszy mieszkaniec, w obecności świadków Lejbusia Bongarta i Wolfa Kopfmana, szkolników, mających po 50 lat, i pokazał nam dziecko płci męskiej, oznajmiając, że ono urodziło się w mieście Tomaszowie drugiego / piętnastego czerwca bieżącego roku o godzinie pierwszej z jego prawowitej żony Chai Gendli z domu Goldach, lat 20. Dziecku temu przy obrzędzie obrzezania dano imiona Hersz Calel (Гершъ Цалель). Akt ten został przeczytany przez nas i przez nich podpisany. Niniejszy akt urodzenia spisał burmistrz N. Jakowlew. [Podpisy] Abram Jakub Kahane (Абрамъ Яковъ Кагане), L. Bongart, W. Kopfman“ (tłum. z języka rosyjskiego).
} 


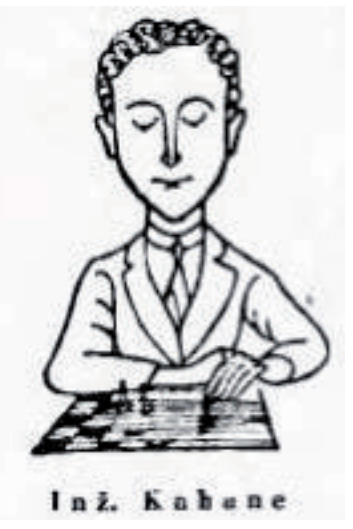

Ilustr. 1. Inż. Henryk Kahane podczas rozgrywki szachowej (karykatura z 1935 r.). Autor nieznany.

Źródło: „Lidové Noviny“ 1935.

gdzie $\mathrm{w}$ okresie międzywojennym mieściła się Wyższa Szkoła Techniczna (czes. Vysoká škola technická v Brně), obecna Politechnika (czes. Vysoké učení technické v Brně) ${ }^{2}$.

\section{Szachowe początki}

W Brnie „Heniek“ (z czeska zwany niekiedy "Jindřichem") był członkiem sekcji szachowej Makkabi, reprezentując ją na mistrzostwach klubu ŠK Aljechin w 1928 r. (wyniki: 1. Marton 7,5 p. z 8 partii, 2. Molisch 7 p., 3. Pollaschek 5,5 p., 4. Kahane 4,5 p. itd.). Ten pierwszy utrwalony przez prasę szachową występ tomaszowskiego szachisty nie zakończył się, jak widać, spektakularnym sukcesem. Należy jednak podkreślić, że czescy rywale Henryka Kahane z roku 1928 bynajmniej nie byli amatorami. Nazwisko studenta Martona nikomu dziś nic mówi, tymczasem w 1927 r. podczas szachowych mistrzostw Rumunii podzielił on miejsca 4-6 $\mathrm{z}$ dr. Baloghiem, wielokrotnym reprezentantem swego kraju na olimpiadach szachowych, i z Mendelssohnem.

Nie ulega najmniejszej wątpliwości, że Henryk Kahane opanował podstawy gry szachowej znacznie wcześniej, w domu rodzinnym lub w szkole, a nie dopiero na studiach w Brnie. Wiadomo też, że rodzina Kahanów przyjaźniła się z inną rodziną tomaszowską Salomonowiczów, gdzie gra w szachy była ceniona i kultywowana. Zachowała się fotografia przedstawiająca braci Salomonowiczów podczas rozgrywania partii szachowej. Wykonano ją podczas I wojny światowej (1914-1918), a zatem w latach, kiedy szachy były szczególnie popularną rozrywką $\mathrm{w}$ środowisku fabrykanckim i inteligenckim Tomaszowa Mazowieckiego. Można zatem podejrzewać, że Henryk

\footnotetext{
2 Na tej samej uczelni studiował także młodszy brat Henryka - Szmul Naftal vel Samuel Kahane (1907-1943?), zwany w kręgu rodzinnym „Mulkiem”, inżynier chemik, absolwent Politechniki w Brnie. Po studiach pracował jako inżynier chemik w Tomaszowskiej Fabryce Sztucznego Jedwabiu. Po napaści hitlerowskiej na Polskę „Mulek” Kahane wraz z ojcem Abramem Jakubem (1886-1943?) i matką Chają Gnendlą z domu Goldach (1886-1943?) opuścił Tomaszów Mazowiecki 6 września 1939 r. i udał się na wschód. Przebywał przez jakiś czas $\mathrm{w}$ Wilnie, skąd utrzymywał kontakt $\mathrm{z}$ rodziną, m.in. $\mathrm{z}$ bratem zamieszkałym $\mathrm{w}$ Rumunii. W 1941 r. został przesiedlony (wraz z rodziną) nad Morze Białe w okolice Archangielska. Tam zaginął bez śladu (ok. 1943 r.). Podobno „Mulek” Kahane miał zamiar udać się do Polskiej Armii. Rodzinie nie udało się nawiązać kontaktu ani z nim, ani z jego rodzicami po zakończeniu II wojny światowej.
} 


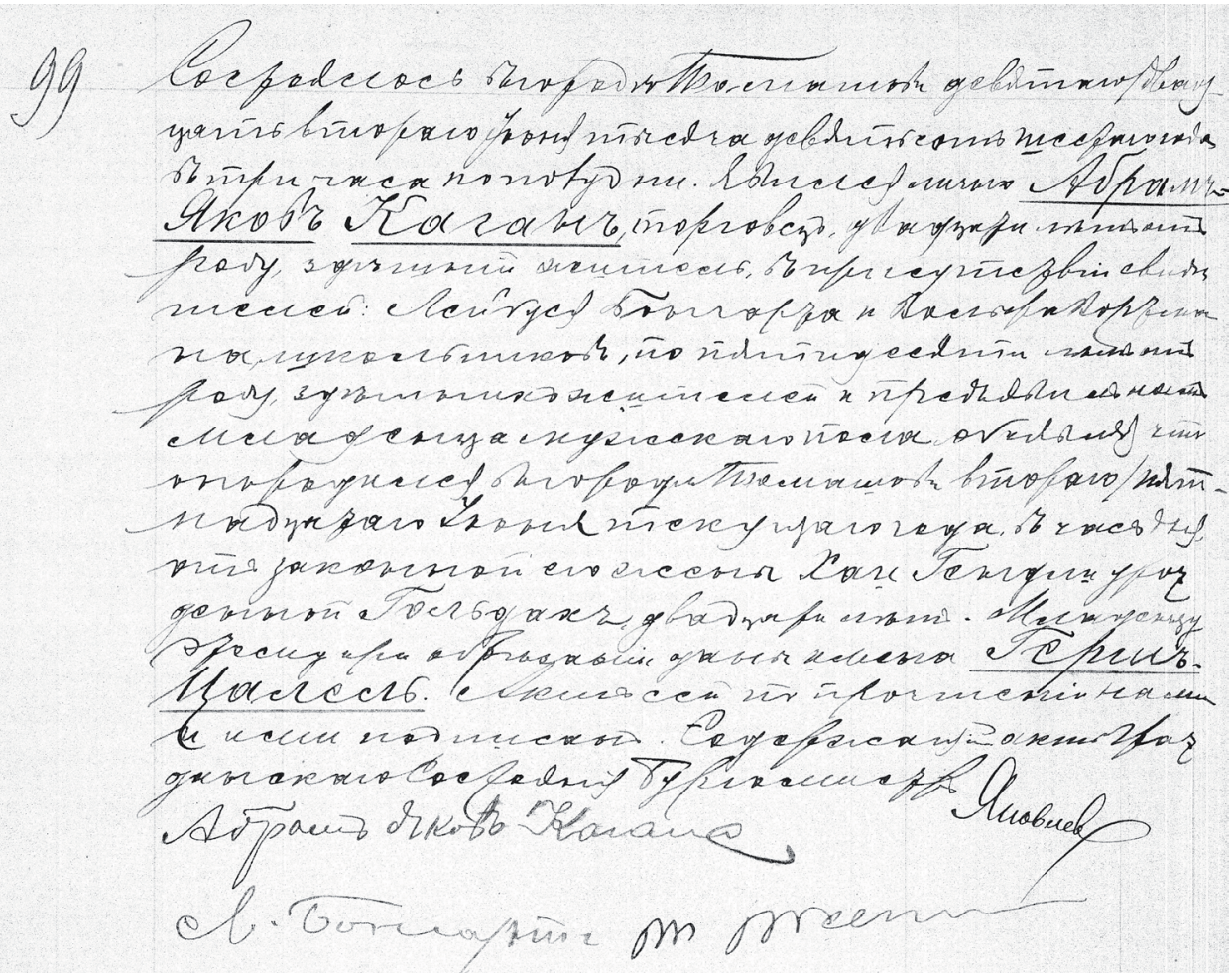

Ilustr. 2. Akt urodzenia Henryka (Hersza Calela) Kahane.

Źródło: Archiwum Państwowe w Piotrkowie Trybunalskim.

Kahane rozgrywał wtedy swoje pierwsze partie szachowe, a jego nauczycielami lub sparring-partnerami mogli być widoczni na zdjęciu (fot. 2.) bracia Salomonowiczowie.

Warto odnotować, że w Tomaszowie Mazowieckim nauczył się grać w szachy Szmul Chaim Rzeszewski (1911-1992), powszechnie znany jako Samuel Reshevsky, arcymistrz szachowy, wielokrotny mistrz Stanów Zjednoczonych Ameryki Północnej, pretendent w rozgrywkach o mistrzostwo świata. Ów młodociany talent nauczył się grać w szachy w wieku czterech lat (zatem w początkowym okresie I wojny światowej) i niebawem dał się poznać jako „Szmulik, cudowne dziecko“ („Szmulik der vunder kind“) w całej Europie (1917-1920), a następnie w Stanach Zjednoczonych (1920-1924)³. Informacje o publicznych występach kilkuletniego Szmulika Rzeszewskiego ukazywały się na łamach ogólnopolskich i lokalnych czasopism, przede wszystkich

3 Zob. K. T. Witczak, Słownik biograficzny Żydów tomaszowskich, Łódź-Tomaszów Mazowiecki 2010, s. 205-207. Fot. 1., umieszczona w tekście, przedstawia siedmioletniego szachistę Szmulika Rzeszewskiego. 


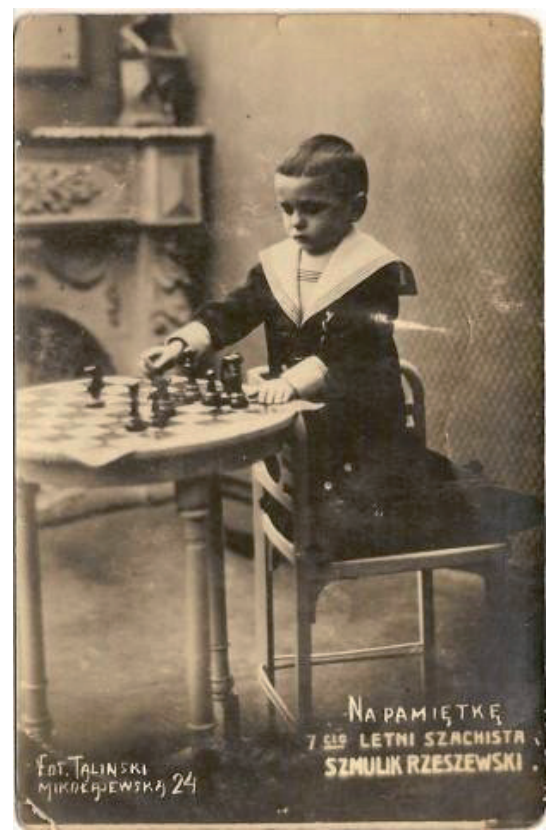

żydowskich, pobudzając młodzież żydowskiego pochodzenia do rozgrywania partii szachowych.

Szachiści tomaszowscy (głównie pochodzenia żydowskiego) spotykali się w lokalu Stowarzyszenia Wzajemnej Pomocy Pracowników Handlowych, założonego w 1912 r. z inicjatywy fabrykanta Wolfa vel Wilhelma Landaua (1863-1942?). Lokal tego stowarzyszenia kulturalnego mieścił się w kamienicy przy ul. Krzyżowej. Powstał tam także żydowski klub szachowy. Niestety, nie zachowały się materiały dotyczące rozgrywanych tam partii, rozgrywek czy turniejów szachowych.

Fot. 1. Szmulik Rzeszewski, cudowne dziecko szachów w 1918 r.

Źródło: Muzeum im. hr. Antoniego Ostrowskiego w Tomaszowie Mazowieckim.

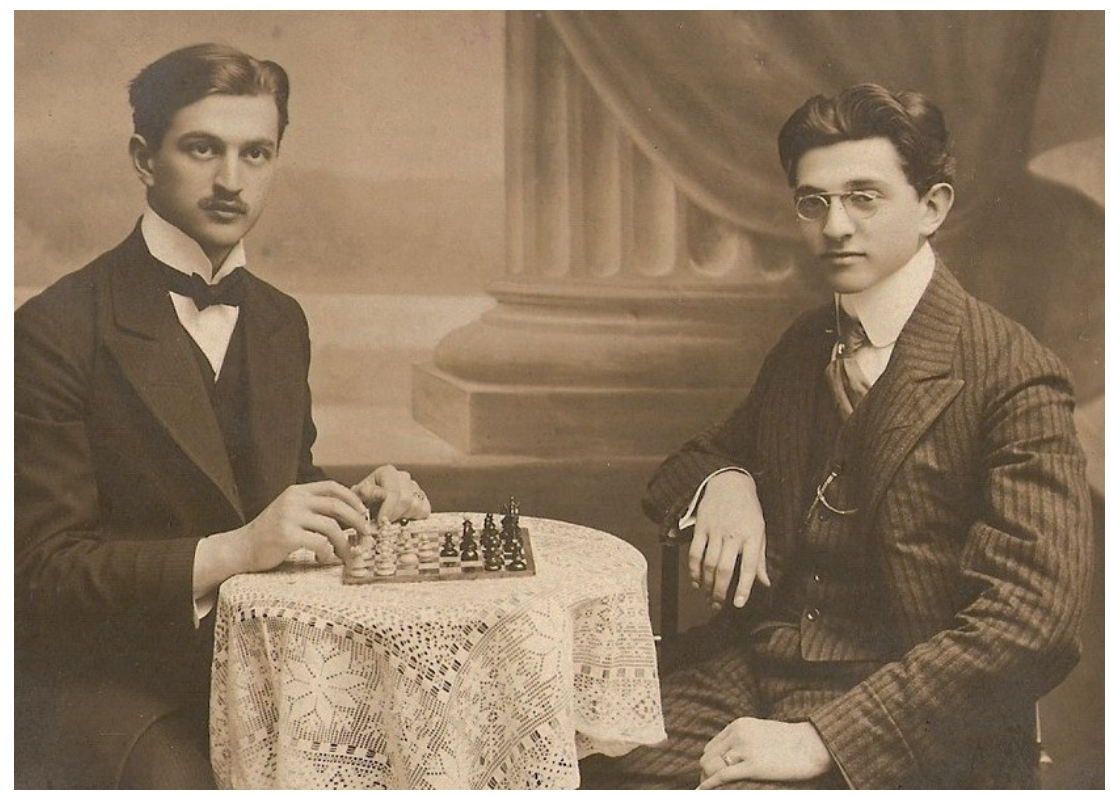

Fot. 2. Jerzy (Icchak) Salomonowicz (ur. 1888) (siedzi po lewej) rozgrywa partię szachową z młodszym bratem Jakubem Salomonowiczem (1891-1954).

Źródło: Zbiory rodzinne Salomonowiczów. Kopia w posiadaniu K.T. Witczaka 


\section{Sukcesy szachowe Henryka Kahane w latach 1929-1931}

Jak wyżej powiedziano, tomaszowianin Henryk (Hersz) Kahane, który z szachami zaznajomił się $\mathrm{w}$ swoim rodzinnym mieście, podczas studiów politechnicznych w Brnie (1927-1931) zostaje członkiem sekcji szachowej Makkabi. Po raz pierwszy staje w szranki szachowej rywalizacji w 1928 r., zajmując dość odległe czwarte miejsce na mistrzostwach klubu ŠK Aljechin.

Student Kahane szybko jednak dojrzewa jako gracz turniejowy. W 1929 r. bierze udział w zjeździe Głównego Związku Czechosłowackich Szachistów (Ústřední jednota československých šachistů) w Brnie i po udanych eliminacjach, wygrywając tzw. turniej główny, zostaje szachowym mistrzem ÚJČš na rok $1929^{4}$.

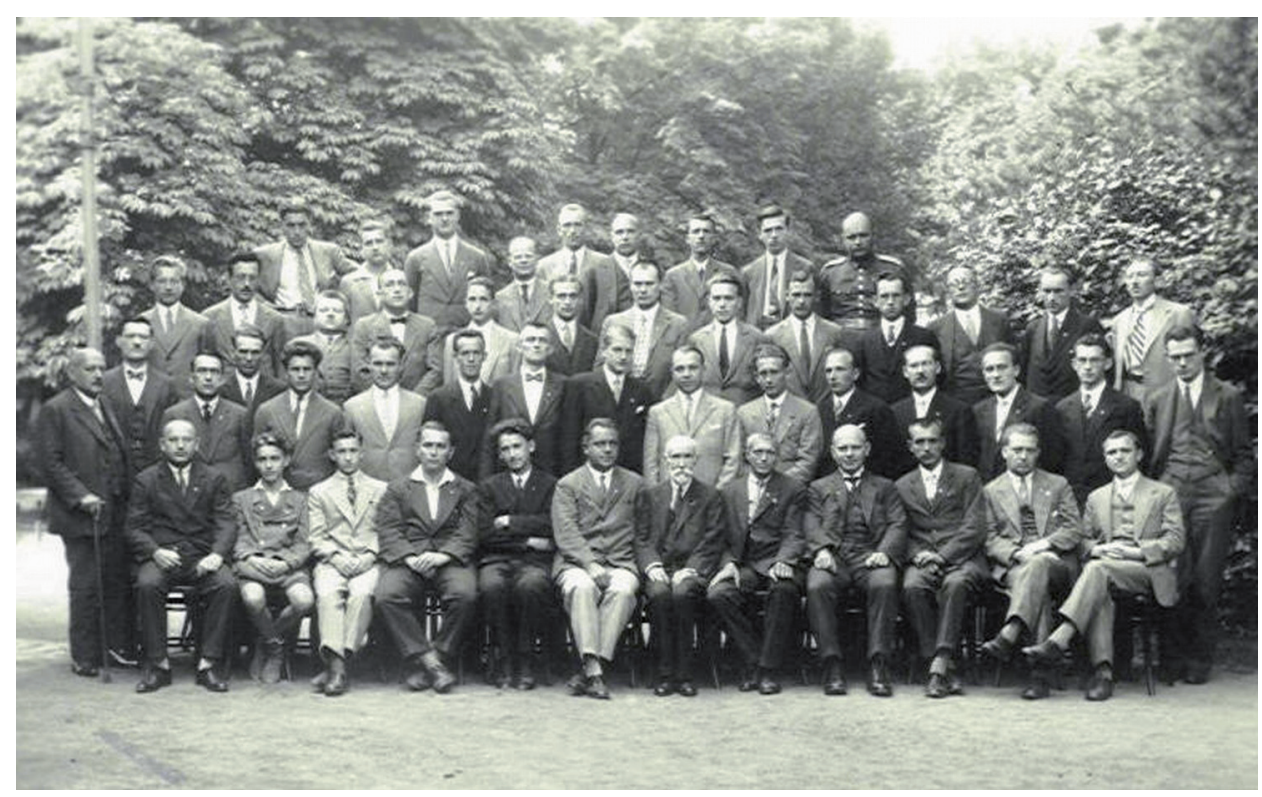

Fot. 3. Uczestnicy turnieju głównego podczas zjazdu ÚJČŠ w Brnie w 1929 r. Źródło: Zbiory Jana Kalendovsky'ego.

4 Turnieju szachowego o mistrzostwo Głównego Związku Czechosłowackich Szachistów (ÚJČŠ), w którym występowali przede wszystkim (choć nie wyłącznie) szachiści-amatorzy, nie należy mylić z turniejem szachistów-profesjonalistów o mistrzostwo Czechosłowacji, który w 1929 r. został również rozegrany w Brnie. Triumfował w nim Karel Opočenský przed Schulzem i Amosem Pokorným. 

Jan Kalendovsky, Tomasz Lissowski, Krzysztof Tomasz Witczak

XI zjazd ÚJČš, Brno 11-24 sierpnia 1929 r.

Turniej główny - III grupa eliminacyjna

\begin{tabular}{|l|l|c|c|c|c|c|c|c|c|c|c|}
\hline \multicolumn{2}{|l|}{} & 1 & 2 & 3 & 4 & 5 & 6 & 7 & 8 & Pkt & \\
\hline 1. Kahane & Brno & - & 0 & 1 & 1 & 1 & 1 & 1 & 1 & 6 & 8 \\
2. Sika & Praha & 1 & - & $\times$ & 1 & 0 & 1 & 1 & 1 & 5,5 & 5 \\
3. Zinner & Brno & 0 & $\times$ & - & 1 & 1 & 1 & 1 & 1 & 5,5 & 6 \\
4. Chrástka & Břeclav & 0 & 0 & 0 & - & 1 & 1 & 1 & 1 & 4 & 3 \\
5. Švéda & Brno & 0 & 1 & 0 & 0 & - & 0 & 1 & 1 & 3 & 2 \\
6. Podhájský & Praha & 0 & 0 & 0 & 0 & 1 & - & 1 & 1 & 3 & 4 \\
7. St. Dienes & Vrútky & 0 & 0 & 0 & 0 & 0 & 0 & - & 1 & 1 & 1 \\
8. Glas & Brno & 0 & 0 & 0 & 0 & 0 & 0 & 0 & - & 0 & 7 \\
\hline
\end{tabular}

Turniej główny - grupa finałowa

\begin{tabular}{|c|c|c|c|c|c|c|c|c|c|c|c|c|c|c|c|c|}
\hline & & & 1 & 2 & 3 & 4 & 5 & 6 & 7 & 8 & 9 & 10 & 11 & 12 & Pkt & \\
\hline 1. & Kahane & Brno & - & $x$ & 0 & 1 & $x$ & 1 & 1 & 1 & 1 & 1 & $x$ & 1 & 8,5 & 3 \\
\hline 2. & Rejdal & Praha & $x$ & - & 0 & $x$ & 1 & 1 & 0 & 1 & 1 & 1 & 1 & 1 & 8 & 8 \\
\hline 3. & Herzog & $\begin{array}{l}\text { Hor. } \\
\text { Růžodol }\end{array}$ & 1 & 1 & - & $x$ & $x$ & $x$ & 0 & 1 & 0 & $x$ & 1 & $x$ & 6,5 & 12 \\
\hline 4. & Novotný & Praha & 0 & $x$ & $x$ & - & $x$ & $x$ & 1 & $x$ & 1 & $x$ & $x$ & 1 & 6,5 & 11 \\
\hline 5. & Paroulek V. & $\begin{array}{l}\text { Podě- } \\
\text { brady }\end{array}$ & $x$ & 0 & $x$ & $x$ & - & $x$ & 1 & 1 & 0 & $x$ & 1 & 1 & 6,5 & 6 \\
\hline 6. & Runza & Praha & 0 & 0 & $x$ & $x$ & $x$ & - & 1 & $x$ & 1 & 1 & $x$ & 1 & 6,5 & 10 \\
\hline 7. & Sika & Praha & 0 & 1 & 1 & 0 & 0 & 0 & - & 0 & 1 & 1 & 1 & 1 & 6 & 7 \\
\hline 8. & Dietze & Praha & 0 & 0 & 0 & $x$ & 0 & $x$ & 1 & - & 1 & 1 & 1 & 0 & 5 & 4 \\
\hline 9. & Sládek & Košice & 0 & 0 & 1 & 0 & 1 & 0 & 0 & 0 & - & 1 & 0 & 1 & 4 & 1 \\
\hline 10. & Bartoš & Cerekvice & 0 & 0 & $x$ & $x$ & $x$ & 0 & 0 & 0 & 0 & - & 1 & $x$ & 3 & 5 \\
\hline 11. & Štěpánek & Praha & $x$ & 0 & 0 & $x$ & 0 & $x$ & 0 & 0 & 1 & 0 & - & $x$ & 3 & 9 \\
\hline 12. & Pour & N. Bydžov & 0 & 0 & $x$ & 0 & 0 & 0 & 0 & 1 & 0 & $x$ & $x$ & - & 2,5 & 2 \\
\hline
\end{tabular}

Jak wynika z powyższego tabelarycznego zestawienia, w turnieju głównym ÚJČŠ zwyciężył obywatel polski pochodzenia żydowskiego Henryk Kahane, reprezentujący środowisko szachowe Brna, student tamtejszej Politechniki, pochodzący z Tomaszowa Mazowieckiego. Zwycięstwo turniejowe było dość nieoczekiwane, ale przekonujące. Tomaszowianin otrzymał nagrodę 800 koron i zaszczytny tytuł mistrza szachowego (mistrza ÚJČŠ). Czeska prasa fachowa tak o turnieju pisała: „Turniej główny nie spełnił być może wszystkich oczekiwań, ale zanotował duży sukces polegający na tym, iż pokazał niepośledni talent kilku młodych adeptów. Przedstawiciele młodzieży zajęli dwa pierwsze miejsca, również inni grali dobrze i zepchnęli starszą generację na dalsze miejsca. Zwycięzcą został polski (a według innych - rumuński) akademik - studiuje w Brnie, zaś pod względem szachowym wyrósł w tamtejszym 
klubie im. Alechina, w barwach którego toczył walkę. [...] Pierwszą nagrodę 800 koron i tytuł mistrza zdobył Kahane. [...] Wysiłek uczestników turnieju głównego był niemały - musieli oni rozegrać 18 partii w 12 dni. Turniej skończył się jednocześnie $\mathrm{z}$ turniejem mistrzowskim w sobotę 24 sierpnia; tego dnia wieczorem odbyło się uroczyste wręczenie nagród" 5 .

Sukces rodaka, podówczas studenta Politechniki w Brnie, skrzętnie odnotowano nad Wisłą. Redagowany przez Dawida Przepiórkę miesięcznik „Świat Szachowy” w rubryce „Wiadomości” poinformował czytelników, iż „w turnieju głównym zdobył Kahane 8,5 p. na 48 uczestników” 6 .

Autorom niniejszego artykułu nie udało się pozyskać podobizny portretowej przedstawiajacej Kahanego z okresu studiów na Politechnice Brneńskiej. Zachowała się jednak fotografia przedstawiająca wszystkich szachistów biorących udział $\mathrm{w}$ turnieju głównym podczas zjazdu Centralnego Związku Czeskosłowackich Szachistów (ÚJČŠ) w Brnie w 1929 r. (zob. fot. 3.), na której na pewno został uwieczniony tomaszowianin.

Niepowodzeniem zakończył się start Kahanego w turnieju o mistrzostwo Brna za rok 1930, do którego stanęło kilku zawodowych szachistów o ugruntowanej renomie. Tomaszowianin zajął miejsce w połowie stawki (8. miejsce na 16 startujących szachistów). Czeska prasa szachowa uznała ten wynik za "rozczarowujący”, gdyż od świeżo wykreowanego mistrza ÚJČŠ (z roku 1929) oczekiwano zdecydowanie lepszego startu.

„Tegoroczny turniej o mistrzostwo Brna, po przegranej mistrza Olexy $\mathrm{w}$ 4. rundzie, przemienił się $\mathrm{w}$ wyścig do pierwszego miejsca pomiędzy mistrzami Tellerem i Pokorným. Nie sposób twierdzić, że Teller miał jakieś nadzwyczajne szczęście, lecz jest faktem, że Pokorný, zwłaszcza w partiach z Tellerem i Zinnerem, nie był wybrańcem losu. Teller grał pewnie i ze wszystkich uczestników najlepiej. Mistrzostwo Brna zdobył już po raz trzeci. Pokorný grał wszystkie partie ostro na wygraną, nie zanotował ani jednego remisu, ale aż trzy partie przegrał, na co nie zasłużył.

W połowie turnieju wydawało się, że obaj wymienieni mistrzowie wyraźnie wyprzedzą pozostałych uczestników, lecz pod koniec turnieju niebezpiecznie zbliżył się do nich mistrz Olexa. Szkoda tylko, że spóźnił się on ze swym finiszem. Również Zinner rozegrał się w drugiej połowie turnieju. Niespodzianką były lokaty Krátký'ego i Švédy. Przegrywając w ostatniej rundzie, szansę na dzielenie miejsc IV-V stracił mistrz Haida. Całkowicie rozczarował mistrz Kahane. Młody Florián to gracz bardzo utalentowany"7.

\footnotetext{
5 „Československý šach” 1929, s. 124.

6 "Świat Szachowy” 1928, nr 8, s. 124.

7 „Československý šach” 1930, s. 91.
} 

Jan Kalendovsky, Tomasz Lissowski, Krzysztof Tomasz Witczak

Mistrzostwa Brna 1930 r.

\begin{tabular}{|c|c|c|c|c|c|c|c|c|c|c|c|c|c|c|c|c|c|}
\hline & 1 & 2 & 3 & 4 & 5 & 6 & 7 & 8 & 9 & 10 & 11 & 12 & 13 & 14 & 15 & 16 & Pkt \\
\hline 1. Teller A. & - & 1 & 1 & $x$ & 1 & $x$ & $x$ & 1 & 1 & 1 & 1 & 1 & $x$ & 1 & 1 & 1 & 13 \\
\hline $\begin{array}{l}\text { 2. Pokor- } \\
\text { ný A. }\end{array}$ & 0 & - & 0 & 0 & 1 & 1 & 1 & 1 & 1 & 1 & 1 & 1 & 1 & 1 & 1 & 1 & 12 \\
\hline 3. Olexa V. & 0 & 1 & - & 0 & $x$ & 1 & 1 & 1 & 1 & 1 & $x$ & 0 & 1 & 1 & 1 & 1 & 11 \\
\hline 4. Zinner E. & $x$ & 1 & 1 & - & 1 & 0 & 0 & 1 & 0 & $x$ & $x$ & 0 & 1 & 1 & 1 & 1 & 9,5 \\
\hline 5. Krátký J. & 0 & 0 & $x$ & 0 & - & 0 & 0 & 1 & $x$ & 1 & 1 & 1 & 1 & 1 & 1 & 1 & 9 \\
\hline 6. Haida A. & $x$ & 0 & 0 & 1 & 1 & - & 0 & 1 & 0 & 0 & 1 & 1 & 1 & 0 & 1 & 1 & 8,5 \\
\hline 7. Švéda J. & $x$ & 0 & 0 & 1 & 1 & 1 & - & $x$ & 0 & $x$ & 0 & 1 & $x$ & 1 & 1 & $x$ & 8,5 \\
\hline 8. Kahane H. & 0 & 0 & 0 & 0 & 0 & 0 & $x$ & - & 1 & $x$ & 0 & 1 & 1 & 1 & 1 & 1 & 7 \\
\hline 9. Florián J. & 0 & 0 & 0 & 1 & $x$ & 1 & 1 & 0 & - & $x$ & 0 & 0 & 1 & $x$ & 0 & 1 & 6,5 \\
\hline 10. Jursa F. & 0 & 0 & 0 & $x$ & 0 & 1 & $x$ & $x$ & $x$ & - & $x$ & 1 & 0 & 1 & 0 & 1 & 6,5 \\
\hline 11. Diesler S. & 0 & 0 & $x$ & $x$ & 0 & 0 & 1 & 1 & 1 & $x$ & - & 0 & $x$ & $x$ & 0 & $x$ & 6 \\
\hline 12. Kvapil L. & 0 & 0 & 1 & 1 & 0 & 0 & 0 & 0 & 1 & 0 & 1 & - & $x$ & $x$ & 1 & 0 & 6 \\
\hline 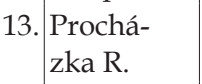 & $x$ & 0 & 0 & 0 & 0 & 0 & $x$ & 0 & 0 & 1 & $x$ & $x$ & - & 1 & 1 & 1 & 6 \\
\hline 14. Malík W. & 0 & 0 & 0 & 0 & 0 & 1 & 0 & 0 & $x$ & 0 & $x$ & $x$ & 0 & - & 1 & 1 & 4,5 \\
\hline 15. Perna A. & 0 & 0 & 0 & 0 & 0 & 0 & 0 & 0 & 1 & 1 & 1 & 0 & 0 & 0 & - & 1 & 4 \\
\hline 16. Bulva F. & 0 & 0 & 0 & 0 & 0 & 0 & $x$ & 0 & 0 & 0 & $x$ & 1 & 0 & 0 & 0 & - & 2 \\
\hline
\end{tabular}

Turniej treningowy mistrzów szachowych ÚJČŠ w Brnie w 1930 r. przed olimpiadą szachową w Hamburgu

\begin{tabular}{|l|l|c|c|c|c|c|c|c|}
\hline \multicolumn{2}{|l|}{} & 1 & 2 & 3 & 4 & 5 & 6 & Pkt \\
\hline 1. & Olexa V. & - & 1 & 1 & 1 & 0 & 1 & 4 \\
2. & Zinner E. & 0 & - & 1 & 1 & 1 & $\times$ & 3,5 \\
3. & Pokorný A. & 0 & 0 & - & 1 & 1 & 1 & 3 \\
4. & Kahane J. & 0 & 0 & 0 & - & 1 & 1 & 2 \\
5. & Pitschak R. & 1 & 0 & 0 & 0 & - & 1 & 2 \\
6. & Haida A. & 0 & $\times$ & 0 & 0 & 0 & - & 0,5 \\
\hline
\end{tabular}

Na pamiętnej dla Polaków olimpiadzie szachowej w Hamburgu - z racji historycznego zwycięstwa drużyny prowadzonej przez legendarnego arcymistrza Akibę Rubinsteina - Amos Pokorný grał w reprezentacji Czechosłowacji na piątej (rezerwowej) szachownicy i uzyskał wynik 7,5 p. z 14 partii. Reprezentacja Czechosłowacji osiągnęła na tej olimpiadzie wysoką, piątą pozycję (z dorobkiem 42,5 p.), ustępując jedynie Polsce, Węgrom, Niemcom i Austrii.

„Organizacja tegorocznego zjazdu okręgowego została powierzona klubowi szachowemu »Duras« z Královego Pola [dzielnica Brna - przyp. aut.]. Dzięki staraniom zarządu klubu z jego prezesem F. Janošem oraz dzięki ofiar- 
VI zjazd Okręgu Brneńskiego, Brno, sierpień 1930 r.

\begin{tabular}{|c|c|c|c|c|c|c|c|c|c|c|c|}
\hline & 1 & 2 & 3 & 4 & 5 & 6 & 7 & 8 & 9 & 10 & Pkt \\
\hline 1. Pitschak R. & - & $x$ & $x$ & $x$ & $x$ & 1 & 1 & 1 & 1 & 1 & 7 \\
\hline 2. Kahane H. & $x$ & - & 0 & 1 & $x$ & $x$ & 1 & 1 & 1 & 1 & 6,5 \\
\hline 3. Molisch & $x$ & 1 & - & 0 & 1 & 0 & 1 & 1 & 1 & 1 & 6,5 \\
\hline 4. Bárta J. & $x$ & 0 & 1 & - & $x$ & 1 & $x$ & 1 & 1 & $x$ & 6 \\
\hline 5. Gargulák M. & $x$ & $x$ & 0 & $x$ & - & $x$ & $x$ & 1 & 1 & 1 & 5,5 \\
\hline 6. Janoš F. & 0 & $x$ & 1 & 0 & $x$ & - & 1 & 1 & $x$ & 1 & 5,5 \\
\hline 7. Florian J. & 0 & 0 & 0 & $x$ & $x$ & 0 & - & $x$ & 1 & 1 & 3,5 \\
\hline 8. Švéda & 0 & 0 & 0 & 0 & 0 & 0 & $x$ & - & 1 & 1 & 2,5 \\
\hline 9. Melčák & 0 & 0 & 0 & 0 & 0 & $x$ & 0 & 0 & - & 1 & 1,5 \\
\hline 10. Perna A. & 0 & 0 & 0 & $x$ & 0 & 0 & 0 & 0 & 0 & - & 0,5 \\
\hline
\end{tabular}

ności i doświadczeniu działaczy: Kvapila, Horáka i Nebesáčka, klub wywiązał się z zadania znakomicie. Cały zjazd odbył się w przyjacielskiej atmosferze. Faworytami turnieju głównego o mistrzostwo województwa byli Kahane i Pitschak, którzy mogli oczekiwać konkurencji tylko ze strony Molischa, Garguláka, Bárty i Janoša. Ta właśnie szóstka graczy zajęła czołowe miejsca. Pitschak nie przegrał żadnej partii i zdobył mistrzostwo województwa na lata 1930-1931. Kahane na początku turnieju zawodził, a gdy już odnalazł formę, było zbyt późno, by odrobić to, co stracił. Molisch ze wszystkich uczestników grał najbardziej pomysłowo i do ostatniej rundy miał realne szanse, by podzielić pierwsze miejsce. Bardzo przyjemną niespodziankę sprawił Bárta, podobnie zresztą jak Janoš. Gargulák utracił wiele ze swojej przysłowiowej twardości i szybko godził się na remis" ${ }^{\prime}$.

Wielkim sukcesem Henryka Kahanego zakończyły się mistrzostwa Brna w roku 1931. Turniej był rozgrywany przez kilka tygodni na przełomie lat 1930-1931. Początkowo nic nie zapowiadało końcowego zwycięstwa tomaszowianina, gdyż Kahane poniósł trzy dotkliwe porażki. Ale jego finisz był naprawdę wspaniały. Udane potyczki z faworytami turnieju Vilemem Olexą i Augustem Haidą, a także efektowne zwycięstwo nad Jozsefem Bartą, głównym - jak się okazało - konkurentem do ostatecznej chwały, pozwoliły mu zdobyć bardzo cenny tytuł szachowego mistrza Brna.

„W turnieju o mistrzostwo Brna na rok 1931 nie wzięło udziału kilku czołowych mistrzów: Pokorný, Burian, Pitschak, Teller, K. Vaněk oraz inż. Berger. Mimo to przebieg turnieju był bardzo interesujący. Za faworyta uchodził mistrz Olexa, ale już w trzeciej rundzie doznał porażki z ręki dobrze grającego Bárty. Po tym nastąpiły kolejne niepowodzenia i Olexa w pierwszej połowie turnieju wypadł z walki o pierwsze miejsce. Gdy kilka rund później doświadczony bojownik A. Haida grał z przedstawicielami młodzie-

\footnotetext{
8 „Československý šach” 1930, s. 144.
} 

Jan Kalendovsky, Tomasz Lissowski, Krzysztof Tomasz Witczak

Mistrzostwa Szachowe Brna 1931 r.

\begin{tabular}{|l|l|c|c|c|c|c|c|c|c|c|c|c|c|c|c|c|c|c|}
\hline \multicolumn{2}{|l|}{} & 1 & 2 & 3 & 4 & 5 & 6 & 7 & 8 & 9 & 10 & 11 & 12 & 13 & 14 & 15 & 16 & Pkt \\
\hline 1. & Kahane & - & 1 & 0 & 0 & 1 & 0 & 1 & 1 & $\times$ & 1 & 1 & 1 & 1 & 1 & 1 & 1 & 11,5 \\
2. & Bárta J. & 0 & - & 1 & 0 & 0 & $\times$ & 1 & 0 & 1 & 1 & 1 & 1 & 1 & 1 & 1 & 1 & 10,5 \\
3. & Hochwald & 1 & 0 & - & 0 & 1 & $\times$ & 1 & 1 & 1 & 0 & 0 & 1 & 1 & 1 & $\times$ & 1 & 10 \\
4. & Zinner E. & 1 & 1 & 1 & - & 1 & 0 & 1 & $\times$ & 0 & 0 & 0 & $\times$ & 1 & 1 & 1 & 1 & 10 \\
5. & Florián J. & 0 & 1 & 0 & 0 & - & 1 & 0 & 0 & $\times$ & 1 & 1 & 1 & 1 & 1 & 1 & 1 & 9,5 \\
6. & Komá- & 1 & $\times$ & $\times$ & 1 & 0 & - & $\times$ & $\times$ & 0 & 0 & $\times$ & 1 & 1 & 1 & 1 & 1 & 9,5 \\
7. & rek F. & & & & & & & & & & & & & & & & & \\
8. & Olexa V. & 0 & 0 & 0 & 0 & 1 & $\times$ & - & $\times$ & 1 & 1 & 1 & 1 & 1 & 0 & 1 & 1 & 9 \\
9. & Haida A. & 0 & 1 & 0 & $\times$ & 1 & $\times$ & $\times$ & - & 0 & 1 & 1 & 1 & 0 & 0 & 1 & 1 & 8,5 \\
10. & Horák & $\times$ & 0 & 0 & 1 & $\times$ & 1 & 0 & 1 & - & $\times$ & 0 & 0 & 1 & 1 & 1 & 1 & 8,5 \\
11. & Molisch & 0 & 0 & 1 & 1 & 0 & 1 & 0 & 0 & $\times$ & - & 0 & 1 & $\times$ & 1 & 1 & 1 & 8 \\
12. & Kvapil & 0 & 0 & 1 & 1 & 0 & $\times$ & 0 & 0 & 1 & 1 & - & 0 & 1 & 1 & 0 & 1 & 7,5 \\
13. & Vanovík & 0 & 0 & 0 & $\times$ & 0 & 0 & 0 & 0 & 1 & 0 & 1 & - & $\times$ & 1 & 1 & $\times$ & 5,5 \\
14. & Janoš F. & 0 & 0 & 0 & 0 & 0 & 0 & 0 & 1 & 0 & $\times$ & 0 & $\times$ & - & $\times$ & 1 & 0 & 3,5 \\
15. & Jursa F. & 0 & 0 & 0 & 0 & 0 & 0 & 1 & 1 & 0 & 0 & 0 & 0 & $\times$ & - & 0 & 1 & 3,5 \\
16. & Kröpa A. & 0 & 0 & $\times$ & 0 & 0 & 0 & 0 & 0 & 0 & 0 & 1 & 0 & 0 & 1 & - & $\times$ & 3 \\
\hline
\end{tabular}

ży: Zinnerem, Bártą, Kahane i drem Hochwaldem, spotkał go podobny los. Zwłaszcza Zinner kroczył od zwycięstwa do zwycięstwa, a towarzyszył mu Bárta, grający w takim turnieju po raz pierwszy. Już wydawało się, że Zinnera nikt nie będzie w stanie zatrzymać i gdy wszyscy typowali go na zwycięzcę, przydarzyło mu się to samo, co byłym liderom Olexie i Haidzie. Dwie porażki wystarczyły, by całkowicie zmienił się obraz turnieju i by na czoło wyszedł mistrz Kahane. Grał on solidne, dobrze przemyślane szachy, a zarówno potrafił wytrwale realizować osiągnięte przewagi, jak i bronić zagrożonych pozycji. Na drugim miejscu uplasował się Bárta, który grał bardzo dobrze i który tym pierwszym swoim sukcesem w Brnie sprawił bardzo miłą niespodziankę. Na miejscach 3-4 znaleźli się dr Hochwald i Zinner, obaj bardzo pomysłowi, agresywni i niebezpieczni zawodnicy"9.

Znakomity czeski szachista Amos Pokorný podkreślał w swoim komentarzu, że polski student Jindřich (tj. Henryk) Kahane zasłużenie zdobył tytuł mistrza Brna: „Nowy mistrz Brna Jindřich Kahane, rodem z Tomaszowa w Polsce, jest słuchaczem brneńskiej politechniki. Na pierwszą nagrodę w pełni zasłużył, wygrywając po ciężkiej walce decydującą partię z Bártą. Solidność i pewność jego gry są tymi cechami, które w dalszym ciągu jego kariery pomogą mu osiągnąć jeszcze niejeden sukces “10.

9 "Československý šach" 1931, s. 54.

10 A. Pokorný, „Lidové noviny" z 25 stycznia 1931 r. 


\section{Henryk Kahane jako szachista okręgu łódzkiego} (1932-1935)

Debiut inż. Henryka (Hersza) Kahanego na arenie krajowej miał miejsce w Łodzi podczas mistrzostw „polskiego Manchesteru” w 1932 r. Trwający ponad miesiąc turniej udowodnił, że do poziomu zawodników aspirujących do polskiej reprezentacji olimpijskiej (Izaak Appel, Teodor Regedziński) brakuje mu jeszcze sporo, ale tomaszowianin prezentuje w dalszym ciągu stabilną i wysoką formę, gdyż skutecznie nawiązuje walkę z szachistami łódzkimi, klasyfikowanymi około dziesiątej pozycji w kraju (Achilles Frydman, Abram Szpiro). Pamiętać należy, że Polska w okresie międzywojennym była potęgą szachową, a Łódź stanowiła (obok Warszawy i Lwowa) przodujący europejski ośrodek szachowy.

Mistrzostwa Łodzi 1932 r.

\begin{tabular}{|c|c|c|c|c|c|c|c|c|c|c|c|c|c|}
\hline & 1 & 2 & 3 & 4 & 5 & 6 & 7 & 8 & 9 & 10 & 11 & 12 & Pkt \\
\hline 1. Appel I. & - & 1 & $x$ & 1 & 1 & 1 & 1 & $x$ & 1 & 1 & 1 & 1 & 10 \\
\hline 2. Regedziński T. & 0 & - & 1 & $x$ & 1 & 1 & $x$ & 1 & 1 & 1 & 1 & 1 & 9 \\
\hline 3. Kolski J. & $x$ & 0 & - & 1 & $x$ & 0 & 1 & 1 & 1 & 0 & 1 & 1 & 7 \\
\hline 4. Kahane H. & 0 & $x$ & 0 & - & $x$ & 1 & 1 & 0 & 1 & 1 & 1 & $x$ & 6,5 \\
\hline 5. Frydman A. & 0 & 0 & $x$ & $x$ & - & 1 & 0 & 1 & $x$ & 1 & $x$ & 1 & 6 \\
\hline 6. Szpiro A. & 0 & 0 & 1 & 0 & 0 & - & 1 & 1 & 0 & $x$ & 1 & 1 & 5,5 \\
\hline 7. Hirszbajn M. & 0 & $x$ & 0 & 0 & 1 & 0 & - & $x$ & 1 & 1 & 1 & 0 & 5 \\
\hline 8. Szestakowski L. & $x$ & 0 & 0 & 1 & 0 & 0 & $x$ & - & $x$ & $x$ & $x$ & 1 & 4,5 \\
\hline 9. GrynfeldI. & 0 & 0 & 0 & 0 & $x$ & 1 & 0 & $x$ & - & 1 & 1 & 0 & 4 \\
\hline 10. Weber & 0 & 0 & 1 & 0 & 0 & $x$ & 0 & $x$ & 0 & - & $x$ & 1 & 3,5 \\
\hline 11. Wróblewski K. & 0 & 0 & 0 & 0 & $x$ & 0 & 0 & $x$ & 0 & $x$ & - & 1 & 2,5 \\
\hline 12. Liebermann & 0 & 0 & 0 & $x$ & 0 & 0 & 1 & 0 & 1 & 0 & 0 & - & 2,5 \\
\hline
\end{tabular}

„W niedzielę 19 czerwca zakończył się turniej szachowy o mistrzostwo Łodzi na rok bieżący, urządzony przez Łódzkie Towarzystwo Zwolenników Gry Szachowej. Pierwszą nagrodę - po raz trzeci z rzędu - zdobył I. Appel, osiągając 10 punktów z 11 możliwych. Jest to już drugi turniej, w którym mistrz Łodzi nie przegrał żadnej partii. Rekordowy wprost wynik ostatniego turnieju Appel zawdzięcza doskonałej formie, w jakiej się obecnie znajduje. Znany zaszczytnie olimpijczyk Teodor Regedziński musiał się zadowolić drugim miejscem, zdobywając 9 punktów. Trzecią nagrodę zdobył Kolski 7 p., który grał stosunkowo słabo, popadając często w trudności. W tegorocznym turnieju grał on bezsprzecznie gorzej, niż w latach ubiegłych. Mamy tu do czynienia z przejściowym spadkiem formy. Czwartą nagrodę zdobył młody i utalentowany szachista inżynier Kahane, który po raz pierwszy debiuto- 
wał w turnieju o mistrzostwo miasta, wykazując bardzo dobrą kombinacyjną grę" 11 .

Prawdopodobnie zawód inżyniera-chemika nie dawał się pogodzić z uprawianiem szachów na wysokim poziomie, skoro w następnym roku Henryk (Hersz) Kahane nie stanął do walki w czempionacie Łodzi (1. Kolski 13 p. z 13 partii!!, 2. Regedziński 11 p., 3. Szpiro 10 p. itd.), natomiast 25 marca 1934 r. pojawił się na Walnym Zgromadzeniu Łódzkiego Okręgowego Związku Szachowego, gdzie został wybrany do trzyosobowego Sądu Honorowego.

Pozycja Kahanego w łódzkim światku szachowym była na tyle wysoka, że w maju tegoż roku został wydelegowany do Katowic na II Drużynowe Mistrzostwa Polski. Drużyna Łodzi grała w składzie: Appel, Regedziński, Kolski, Szpiro, Kahane i Grynfeld (rezerwowy gracz inż. Krakowski nie wystąpił w żadnym meczu). Począwszy od pierwszej rundy, walka o prymat toczyła się - zgodnie z ogólnymi przewidywaniami - pomiędzy Warszawą i Łodzią, środek tabeli tworzyły drużyny Lwowa, Krakowa i Śląska, natomiast tabelę zamykały Pomorze, Wilno i Poznań. Turniej wymagał dobrej kondycji, dziennie bowiem grano dwie rundy, od godziny 9.00 do 13.30 i po przerwie obiadowej od 17.00 do 22.30 .

Wkład Kahanego do dorobku punktowego drużyny Łodzi nie był szczególnie imponujący. Na starcie przegrał dwie partie: z Krystą (Śląsk) i Metzgerem (Lwów), a następnie dwie partie zremisował: z Tylkowskim (Poznań) i Błaszczakiem (Kraków). W meczu z Wilnem Kahane wreszcie pokonuje Borkuma, a drużyna łódzka zwycięża w stosunku 5,5 do 0,5 i wychodzi na prowadzenie przed Warszawą. W szóstej rundzie Kahane remisuje z mało znanym graczem Pomorza Cerkaskim, co oczywiście jest sukcesem dla tego drugiego. Wreszcie w ostatniej rundzie Łódź gra mecz „o wszystko” z Warszawą, Kahane wygrywa partię ze Zbigniewem Millerem (przyszłym prezesem Polskiego Związku Szachowego), ale wobec świetnej gry stołecznego duetu Przepiórka - Najdorf mecz kończy się remisem 3:3, co daje pierwsze miejsce $w$ turnieju drużynie warszawskiej ${ }^{12}$. Ambitni łodzianie muszą się zadowolić drugim miejscem.

Drugie Drużynowe Mistrzostwa Polski, Katowice 1934 r.

$\begin{array}{llll}\text { 1. Warszawa } & 29,5 & \text { 5. Śląsk } & 18,5 \\ \text { 2. Lódź } & \mathbf{2 9} & \text { 6. Pomorze } & 15,5 \\ \text { 3. Lwów } & 25 & \text { 7. Wilno } & 14,5 \\ \text { 4. Kraków } & 23 & \text { 8. Poznań } & 13\end{array}$

11 „Świat Szachowy” 1932, nr 6, s. 81-82.

12 Należy zaznaczyć, że potyczka Mieczysława Najdorfa (Warszawa) z Teodorem Regedzińskim (Łódź) na drugiej szachownicy „w powszechnym odczuciu była najefektowniejszą w całym turnieju", zob. T. Wolsza, Najdorf. Z Warszawy do Buenos Aires, Warszawa 2010, s. 16. 
Klasyfikacja na piątej szachownicy: Schächter (Lwów) 6, Błaszczak (Kraków) 4,5, Miller (Warszawa) 4,5, Kahane (Łódź) 3,5, Krysta (Śląsk) 2,5, Tylkowski (Poznań) 2,5, Borkum (Wilno) i Cerkaski (Pomorze) - po 2, Stankiewicz 1,5 (Wilno, rezerwa).

Turniej zakończył się wieczorem 14 maja 1934 roku uroczystym bankietem $\mathrm{w}$ hotelu Savoy, gdzie - jak pisał autor sprawozdania w miesięczniku „Szachista” mgr Julian Madfes, „wśród serdecznego nastroju zacieśniono węzły przyjaźni zadzierżgnięte przy bezkrwawej walce przy szachownicy“13.

Jesienią tego samego roku zakończył się turniej o mistrzostwo Łodzi z udziałem całej czołówki. Rozgrywano jedną partię tygodniowo - zawsze $\mathrm{w}$ środę. Po raz kolejny szachowym mistrzem miasta Łodzi został Izaak Appel, który okazał się bezlitosnym „katem” dla nieco słabszych konkurentów. Kahane zajął ostatecznie znakomite trzecie miejsce, zdobywając 10,5 p. z 14 partii. Był jedynym zawodnikiem, który odniósł zwycięstwo nad mistrzem Appelem (11 p.), ale doznał trzech porażek w potyczkach z renomowanymi szachistami łódzkimi: z Kolskim (zajął 2. miejsce z dorobkiem 10,5p.), Regedzińskim i Szpiro.

Mistrzostwa Łodzi 1934 r.

\begin{tabular}{|l|l|c|c|c|c|c|c|c|c|c|c|c|c|c|c|c|c|}
\hline \multicolumn{2}{|l|}{} & 1 & 2 & 3 & 4 & 5 & 6 & 7 & 8 & 9 & 10 & 11 & 12 & 13 & 14 & 15 & Pkt \\
\hline 1. & Appel I. & - & $\times$ & 0 & $\times$ & $\times$ & $\times$ & 1 & 1 & 1 & 1 & 1 & 1 & 1 & 1 & 1 & 11 \\
2. & Kolski J. & $\times$ & - & 1 & $\times$ & 1 & 1 & 0 & 1 & $\times$ & $\times$ & 1 & 1 & 1 & $\times$ & 1 & 10,5 \\
3. & Kahane H. & 1 & 0 & - & $\times$ & 0 & 0 & 1 & 1 & 1 & 1 & 1 & 1 & 1 & 1 & 1 & 10,5 \\
4. & Frydman A. & $\times$ & $\times$ & $\times$ & - & 0 & 1 & 1 & $\times$ & 1 & $\times$ & 1 & 0 & 1 & 1 & 1 & 9,5 \\
5. & Regedziński T. & $\times$ & 0 & 1 & 1 & - & 0 & $\times$ & 1 & $\times$ & 1 & 1 & 0 & $\times$ & 1 & 1 & 9 \\
6. & Szpiro A. & $\times$ & 0 & 1 & 0 & 1 & - & 1 & 0 & 0 & 1 & $\times$ & 1 & 1 & 0 & 1 & 8 \\
7. & Grynfeld I. & 0 & 1 & 0 & 0 & $\times$ & 0 & - & $\times$ & 0 & $\times$ & 1 & 1 & 1 & 1 & 1 & 7,5 \\
8. & Hirszbajn M. & 0 & 0 & 0 & $\times$ & 0 & 1 & $\times$ & - & 1 & $\times$ & 0 & $\times$ & 1 & 1 & 1 & 7 \\
9. & Landau & 0 & $\times$ & 0 & 0 & $\times$ & 1 & 1 & 0 & - & 0 & 0 & 1 & 1 & 1 & $\times$ & 6,5 \\
10. & Michalec Ch. & 0 & $\times$ & 0 & $\times$ & 0 & 0 & $\times$ & $\times$ & 1 & - & 1 & 1 & 0 & $\times$ & 1 & 6,5 \\
11. & Wojdysławski & 0 & 0 & 0 & 0 & 0 & $\times$ & 0 & 1 & 1 & 0 & - & 1 & 1 & 1 & 1 & 6,5 \\
12. & Szapiro S. & 0 & 0 & 0 & 1 & 1 & 0 & 0 & $\times$ & 0 & 0 & 0 & - & 0 & 1 & 1 & 4,5 \\
13. & Weber & 0 & 0 & 0 & 0 & $\times$ & 0 & 0 & 0 & 0 & 1 & 0 & 1 & - & 1 & 0 & 3,5 \\
14. Szestakowski L. & 0 & $\times$ & 0 & 0 & 0 & 1 & 0 & 0 & 0 & $\times$ & 0 & 0 & 0 & - & 1 & 3 \\
15. & Glicensztejn & 0 & 0 & 0 & 0 & 0 & 0 & 0 & 0 & $\times$ & 0 & 0 & 0 & 1 & 0 & - & 1,5 \\
\hline
\end{tabular}

W sprawozdaniu dla lwowskiego miesięcznika szachowego profesor (prawdopodobnie gimnazjalny) Antoni Kościelak, sam zapalony gracz korespondencyjny, pisał: „Turniej o mistrzostwo Łodzi należy do najpoważniej-

13 „Szachista” 1934, nr 6-7, s. 90. 
szych naszych imprez szachowych, tradycyjnie biorą w nim udział najlepsi szachiści łódzcy. Zgromadził on na starcie 15 zawodników i wzbudził wielkie zainteresowanie wśród zwolenników gry królewskiej. [...] Gra odbywała się w Łódzkim Towarzystwie Zwolenników Gry Szachowej w środę każdego tygodnia. Jeżeli teraz przejdziemy do omówienia poszczególnych rezultatów turnieju, to na pierwszym miejscu wspomnieć musimy o Appelu, który już po raz piąty z rzędu zdobywa tytuł mistrza Łodzi i pierwszą nagrodę. Dowiódł on swym wynikiem, że jest ciągle pełnowartościowym mistrzem o logicznej grze pozycyjnej. Przegrał jedną grę, z inż. Kahane. Drugą i trzecią nagrodę podzielili - Kolski i inż. Kahane. [...] Rekord co do ilości wygranych partyj osiągnął inż. Kahane. Wynik jego, 10 wygranych z 14 partyj, uważać należy za bardzo trudny do pobicia.Wykazał on wysoką klasę w całym szeregu partyj, a najbardziej cennym punktem była wygrana z Applem“"14.

Wyniki turnieju doczekały się komentarza ze strony czeskich szachistów: „Był to bardzo silny turniej, który pokazuje, że między Łodzią i Warszawą trwa stała rywalizacja, jak u nas między Brnem i Pragą. Szachistom z Brna jest dobrze znany inż. Kahane, który ma za sobą brneńską szkołę szachową, a raz był nawet mistrzem Brna. Turniej udowodnił, że tytuł mistrza ÚJČŠ również za granicą ma pewną wartość" - pisał Amos Pokorný ${ }^{15}$.

Mecze pomiędzy szachowymi reprezentacjami Łodzi i Warszawy miały długą tradycję. Pierwszy odbył się we wrześniu 1922 r. w Łodzi; drużyna stołeczna z Aleksandrem Flambergiem, Mojżeszem Łowckim i Dawidem Przepiórką na czele wygrała dwukołowe spotkanie w stosunku 11,5:6,5. Na początku $1935 \mathrm{r}$. nastąpiła kolejna (a zarazem ostatnia w okresie przedwojennym) odsłona pryncypialnego pojedynku pomiędzy dwoma najsilniejszymi ośrodkami szachowymi w kraju. Jednorundowy tym razem mecz na dziesięciu szachownicach odbył się 16 lutego w nowym („luksusowo urządzonym" - jak donosił miesięcznik "Szachista") lokalu Łódzkiego Towarzystwa Zwolenników Gry Szachowej przy ul. Piotrkowskiej 74. Łodzianie wygrali zasłużenie 6:4, a największą niespodziankę sprawił Jakub Kolski, wygrywając z chimerycznym Mieczysławem Najdorfem. Wielka rutyna nie uchroniła od porażki Leona Kremera w partii z Izaakiem Grynfeldem oraz Achillesa Frydmana w partii z M. Klepfiszem; w tym ostatnim niektórzy autorzy upatrują studenta Politechniki Warszawskiego Michała Klepfisza (1913-1943), przyszłego bohatera warszawskiego getta ${ }^{16}$. Przepiórka po spokojnej grze zremisował z wielokrotnym olimpijczykiem Regedzińskim. Pod pseudoni-

14 "Szachista” 1934, nr 12, s. 185-186.

15 A. Pokorny , „Lidové Noviny” 1935.

${ }^{16}$ Zob. A.K. Kunert, Stownik biograficzny konspiracji warszawskiej 1939-1945, t. 2, Warszawa 1987, s. 85-86. Oprócz szachów Michał Klepfisz uprawiał także lekkoatletykę. Od roku 1937 pełnił funkcję kierownika sekcji lekkoatletycznej SRWF Jutrznia Warszawa. 
mem „Szeffer” krył się Salomon Szapiro (1882-1944?), doktor medycyny, a zarazem autor komentarzy do Starego Testamentu ${ }^{17}$.

$\begin{array}{llll}\text { Appel I. } & - & \text { Łowcki M. } & 1 / 2 \\ \text { Grynfeld I. } & - & \text { Kremer L. } & 1: 0 \\ \text { Regedziński T. } & - & \text { Przepiórka D. } & 1 / 2 \\ \text { "Szeffer" S. } & - & \text { Stückgold I. } & 1: 0 \\ \text { Ziemiński } & - & \text { Jagielski J. } & 1: 0 \\ \text { Frydman A. } & - & \text { Klepfisz M. } & 0: 1 \\ \text { Hirszbajn M. } & - & \text { Tuhan-Baranowski L. } & 1 / 2 \\ \text { Kahane H. } & - & \text { Sternfeld J. } & 1 / 2 \\ \text { Kolski J. } & - & \text { Najdorf M. } & 1: 0 \\ \text { Szpiro A. } & - & \text { Młynek H. } & 0: 1\end{array}$

Po meczu odbył się bankiet, na którym obecni byli, obok uczestników meczu, działacze Polskiego Związku Szachowego (Kazimierz Piłsudski, dr Bronisław Nakoniecznikow-Klukowski, płk Marian Steifer).

Następnego dnia, również w lokalu klubu łódzkiego, rozpoczął się turniej kwalifikacyjny przed III Mistrzostwami Polski, imprezy stanowiącej z kolei jeden z etapów wyłonienia reprezentacji krajowej na zbliżającą się Olimpiadę Szachową w Warszawie (16-31 sierpnia 1935 r.). Na starcie stanęło 15 zawodników reprezentujących najważniejsze ośrodki: Lwów (Henryk Friedman, Izaak Schächter i Edward Gerstenfeld), Łódź (Achilles Frydman, Abram Szpiro i Kahane), Warszawę (Henryk Młynek, Jakub Sternfeld), Poznań (Leon Widermański), Pomorze (Antoni Wojciechowski), Wilno (Kazimierz Plater), Białystok (Nowodworski), Kraków (Abraham) i Śląsk (Stanisław Zawadzki). Imienne zaproszenie przyjął sędziwy (rocznik 1863) maestro Ignacy hr. Popiel, którego debiut międzynarodowy miał miejsce podczas kongresu Niemieckiego Związku Szachowego w 1889 r. we Wrocławiu, gdzie jednym z jego przeciwników był nikomu nieznany student Emanuel Lasker, przyszły mistrz świata.

„Już pierwsze dni turnieju wykazały, że na dobre wyniki graczy złożą się przede wszystkim, obok talentu i zdolności, także wytrwałość i kondycja fizyczna. Gra bowiem odbywała się codziennie w godzinach od 9-ej do 14-ej i od 17-ej do 22-ej, czyli razem 10 godzin dziennie, zaś raz na 4 dni zarządzana była 1 runda oraz dokończenie partyj zawieszonych. W tych warunkach zdobycie dobrego miejsca w turnieju było rzeczą bardzo trudną i już po kilku dniach gry widoczne było zmęczenie nawet u zawodników rutynowanych"18.

17 T. Wolsza, "Dr Szeffer", [w:] tegoż, Arcymistrzowie, mistrzowie, amatorzy... Stownik biograficzny szachistów, t. 4, Warszawa 2003, s. 120-122.

18 „Szachista” 1935, nr 4, s. 50. 

Jan Kalendovsky, Tomasz Lissowski, Krzysztof Tomasz Witczak

Turniej kwalifikacyjny, Łódź 17-24 lutego 1935 r.

\begin{tabular}{|l|c|c|c|c|c|c|c|c|c|c|c|c|c|c|c|c|}
\hline \multicolumn{2}{|l|}{} & 1 & 2 & 3 & 4 & 5 & 6 & 7 & 8 & 9 & 10 & 11 & 12 & 13 & 14 & Pkt \\
\hline 1. & Friedman H. & - & $\mathrm{x}$ & $\mathrm{x}$ & 1 & $\mathrm{x}$ & 1 & $\mathrm{x}$ & $\mathrm{x}$ & 1 & 0 & 1 & 1 & 1 & $\mathrm{x}$ & 9 \\
2. & Frydman A. & $\mathrm{x}$ & - & $\mathrm{x}$ & 0 & 1 & 0 & 1 & 0 & 1 & $\mathrm{x}$ & 1 & 1 & 1 & 1 & 8,5 \\
4. & Gerstenfeld E. & $\mathrm{x}$ & $\mathrm{x}$ & - & 1 & $\mathrm{x}$ & 1 & 1 & $\mathrm{x}$ & 0 & 0 & 1 & 1 & 1 & $\mathrm{x}$ & 8,5 \\
5. & Szpiro A. & 0 & 1 & 0 & - & 0 & 1 & 1 & 1 & 1 & 1 & 0 & 1 & $\mathrm{x}$ & 1 & 8,5 \\
6. & Schächter I. & $\mathrm{x}$ & 0 & $\mathrm{x}$ & 1 & - & 0 & $\mathrm{x}$ & 1 & 1 & 1 & 0 & 1 & 1 & 1 & 8,5 \\
7. & Młynek H. & 0 & 1 & 0 & 0 & 1 & - & 0 & 1 & $\mathrm{x}$ & 1 & 1 & 0 & 1 & $\mathrm{x}$ & 7 \\
8. & Kahane H. & $\mathrm{x}$ & 0 & 0 & 0 & $\mathrm{x}$ & 1 & - & 1 & 0 & 1 & $\mathrm{x}$ & 1 & 0 & 1 & 6,5 \\
9. & Wojciechowski A. & $\mathrm{x}$ & 1 & $\mathrm{x}$ & 0 & 0 & 0 & 0 & - & $\mathrm{x}$ & 1 & $\mathrm{x}$ & $\mathrm{x}$ & 1 & 1 & 6,5 \\
10. & Zawadzki S. & 0 & 0 & 1 & 0 & 0 & $\mathrm{x}$ & 1 & $\mathrm{x}$ & - & $\mathrm{x}$ & $\mathrm{x}$ & 0 & 1 & 1 & 6 \\
11. & Nowodworski A. & 1 & $\mathrm{x}$ & 1 & 0 & 0 & 0 & 0 & 0 & $\mathrm{x}$ & - & $\mathrm{x}$ & $\mathrm{x}$ & $\mathrm{x}$ & 1 & 5,5 \\
12. & 0 & 0 & 0 & 1 & 1 & 0 & $\mathrm{x}$ & $\mathrm{x}$ & $\mathrm{x}$ & $\mathrm{x}$ & - & 0 & 0 & 1 & 5 \\
13. & Widermański L. & 0 & 0 & 0 & 0 & 0 & 1 & 0 & $\mathrm{x}$ & 1 & $\mathrm{x}$ & 1 & - & 0 & $\mathrm{x}$ & 4,5 \\
14. & Popiel I. & 0 & 0 & 0 & $\mathrm{x}$ & 0 & 0 & 1 & 0 & 0 & $\mathrm{x}$ & 1 & 1 & - & 0 & 4 \\
\hline
\end{tabular}

W połowie dystansu wycofał się zawodnik warszawski Sternfeld, posiadający na koncie 2,5 p. z 6 gier. Inż. Henryk Kahane, nieprzyzwyczajony do tak dużej porcji gry, dzień po dniu, po początkowych sukcesach wypadł z czołówki, kończąc turniej w środku tabeli. Prasa szachowa odnotowała kilka jego partii; niestety, wyłącznie przegrane.

Dawid Daniuszewski ${ }^{19}$ opublikował fotografię zbiorową uczestników i organizatorów turnieju kwalifikacyjnego w Łodzi (wykonaną w lutym 1935 r.) z dokładnym wykazem osób na niej uwiecznionych. Inż. Henryk Kahane stoi czwarty od prawej strony.

Turniej eliminacyjny w Łodzi był prawdopodobnie ostatnim występem Kahanego na arenie krajowej. $\mathrm{W}$ tym samym roku wyjechał do Rumunii, gdzie założył fabrykę chemiczną. Jego wspólnikiem był, jakżeby inaczej, dobry znajomy z Tomaszowa Jakub Salomonowicz. Po kilku latach, w obawie przed wzbierającą falą nazizmu, Kahane opuścił ledwie poznaną Rumunię, docierając przez Bułgarię i Turcję do Palestyny. W Ramat Gan otworzył fabrykę chemiczną Avipun, której był wieloletnim dyrektorem. Zmarł w Tel Awiwie po odejściu na zasłużoną emeryturę, ale dokładnej daty zgonu nie

19 Postać Dawida Daniuszewskiego (1885-1944), wybitnego szachisty, reprezentanta Polski na I Olimpiadzie Szachowej w Paryżu (10-24 lipca 1924 r.), publicysty, propagatora gier umysłowych, autora publikacji szachowych, najpełniej prezentuje praca: T. Lissowski, W. Czaruszyn, Daniuszewski - nieznany rywal Alechina, Warszawa 1999. Zob. też T. Wolsza, Kronikarz Łódzkiego Towarzystwa Zwolenników Gry Szachowej, [w:] tegoż, Arcymistrzowie, mistrzowie, amatorzy..., t. 4, s. 19-28. 


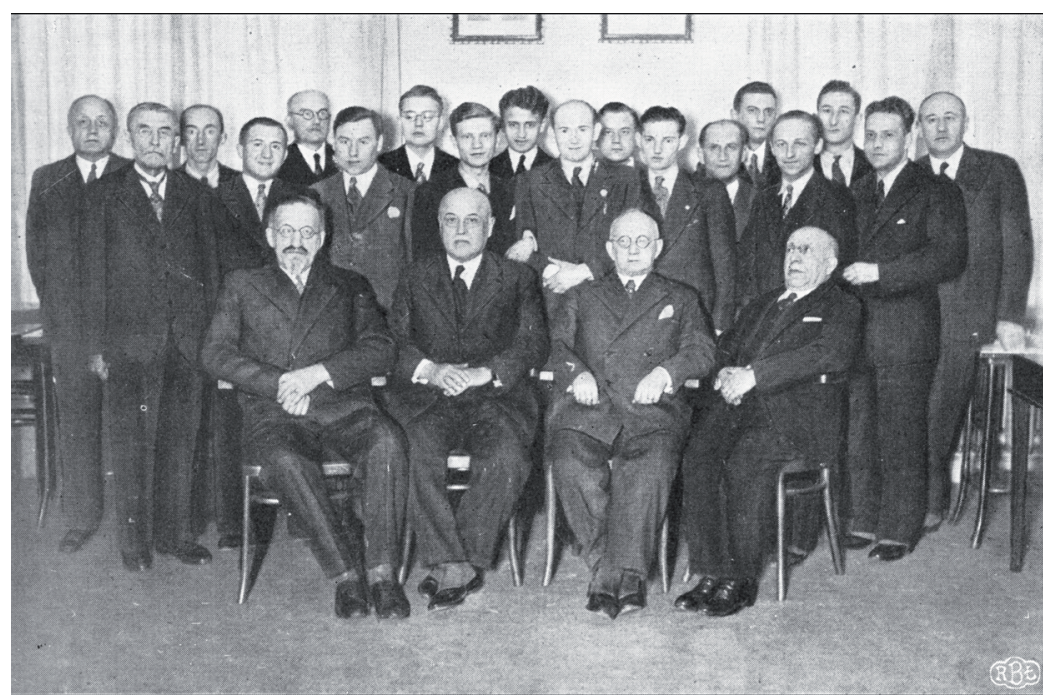

Fot. 4. Uczestnicy i organizatorzy turnieju kwalifikacyjnego w Łodzi. Od lewej stoją: Katajew (kierownik turnieju), I. Popiel, A. Abraham, A. Szpiro, S. Zawadzki, prof. A. Kościelak (członek komitetu organizacyjnego), K. Plater, E. Gerstenfeld, H. Młynek, H. Friedman, L. Widermański, I. Schächter, L. Szestakowski (członek Zarządu ŁTZGSz), A. Wojciechowski, inż. H. Kahane, A. Nowodworski, A. Frydman, Landau (członek zarządu ETZGSz.). Od lewej siedzą: M. Halpern,

S. Rozenblat, M. Weinreich i M. Małachowski - członkowie zarządu ŁTZGSz.

Źródło: D. Daniuszewski, Księga jubileuszowa Łódzkiego Towarzystwa Zwolenników Gry Szachowej wydana z okazji XXXV-lecia 1903-1938, Łódź 1938, wkładka pomiędzy s. 136 i 137.

znamy. Pozostawił jedyne dziecko - córkę Judit, która urodziła się na terenie Turcji.

Niestety, nie wiemy, czy Henryk Kahane uczestniczył w turniejach lub rozgrywkach szachowych w późniejszym czasie (np. w Rumunii lub w Izraelu) ${ }^{20}$.

\section{Zadania szachowe}

Głęboka wiedza szachowa i bogata fantazja popychała Henryka Kahanego również w stronę innych form twórczości. Tomaszowianin zajmował się np. komponowaniem zadań szachowych, o czym donosiła polska prasa specjalistyczna okresu międzywojennego: „Rok 1934 był przełomowym w rozwoju

${ }^{20}$ W roku 1954 w czasopiśmie „Bulletin Ouvrier des Échecs“ (nr 90/91), ukazującym się w mieście Ivry we Francji, pojawił się zapis partii szachowej pomiędzy E. Kahanem i M. Bobocovem, granej w tymże roku w Bułgarii. Nie ma pewności, czy ów E. Kahane był tożsamy z tomaszowskim szachistą Henrykiem Kahane. 


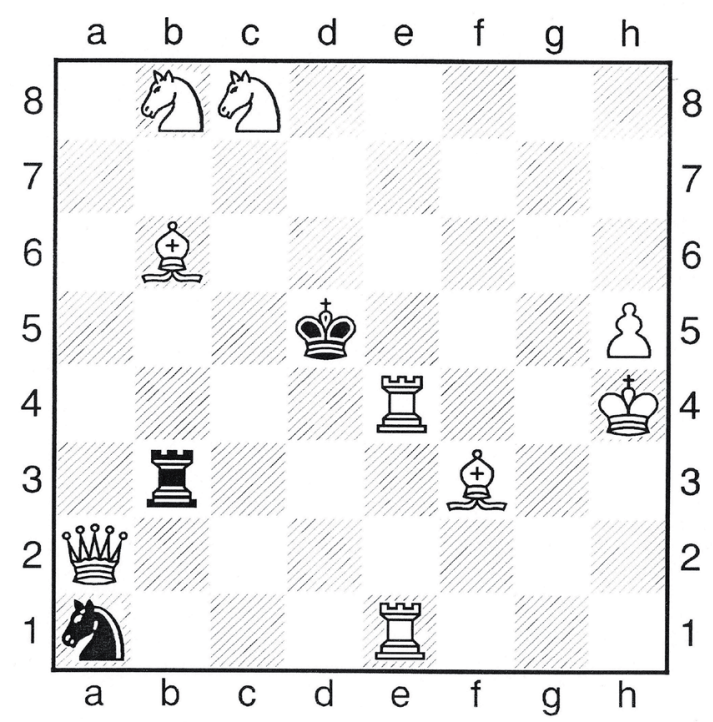

Ilustr. 3. Inż. H. Kahane (Brno), Samomat w 5 pos. (oryginał)

Białe zaczynają i zmuszają czarne, by dały im mata w piątym posunięciu.

Rozwiązanie zadania: 1.Gh1 Sc2 2.Se7+ Kd6 3.Wd4+ Sxd4 4.Hh2+ Wg3 5.Sf5+ Sxf5 mat.

Źródło: „Národni Listy” 1931, rubryka redagowana przez F. J. Prokopa.

założonej w 1929 r. Sekcji Szachowej K.S. Makabi Łódź. Sekcja się silnie rozwinęła i liczyła z końcem 1934 przeszło 80 członków. Dzięki inicjatywie ruchliwego zarządu, na czele którego stał p. M. Spektor, został przeprowadzony cały szereg imprez szachowych. [...] Wśród członków sekcji znajduje się i cały szereg kompozytorów, m.in. znani w Polsce S. Kozłowski (końcówki) i Gotfried oraz początkujący inż. Kahane, Kochański, Majzner“ ${ }^{21}$.

Debiut tomaszowianina jako autora szachowych „łamigłówek” miał miejsce jeszcze podczas pobytu w Czechosłowacji w roku 1921. Zob. Ilustr. 3.

Autorzy niniejszego tekstu ograniczają prezentację kompozycyjnych dokonań młodego tomaszowianina do tej debiutanckiej „łamigłówki”. 


\author{
Jan Kalendovsky \\ Tomasz Lissowski \\ Krzysztof Tomasz Witczak
}

\title{
Henryk Kahane - zapomniany mistrz szachowy
}

\begin{abstract}
Streszczenie
Tekst przedstawia karierę szachisty Henryka Kahane. Henryk (Hersz Tsalel) Kahane urodził się w Tomaszowie Rawskim (Mazowieckim) w 1906 roku i uczył się grać w szachy w swoim rodzinnym mieście. Później studiował chemię na Politechnice w Brnie w latach 1927-1931. Reprezentując żydowski klub Makkabi Brno, Kahane został mistrzem Głównego Związku Czechosłowackich Szachistów (ÚJČŠ) w roku 1929 na turnieju rozgrywanym w Brnie, a w roku 1931 został szachowym mistrzem Brna. Po powrocie do Polski Kahane był członkiem Łódzkiego Towarzystwa Zwolenników Gry Szachowej. Brał udział w Szachowych Mistrzostwach Łodzi (4 miejsce w 1932 roku, 3 miejsce w 1934), był także członkiem zespołu Łodzi na Mistrzostwa Polski w szachach w 1934 r. W 1935 r. wyemigrował do Rumunii, później (1940), poprzez Bułgarię i Turcję do Palestyny. W Izraelu Henryk Kahane mieszkał w mieście Ramat Gan (Dystrykt Tel Awiw), gdzie założył fabrykę chemiczną, której był dyrektorem. Nie wiadomo, czy w Izraelu grał w szachy i nieznana jest data jego śmierci.
\end{abstract}

\section{Henryk Kahane - a forgotten chess master}

\begin{abstract}
The article presents the career of a chess player, Henryk Kahane. Henryk (Hersz Tsalel) Kahane was born in Tomaszów Rawski (Tomaszów Mazowiecki) in 1906 and learned to play chess in his home town. Later, in the years 1927-1931, he studied chemistry at the Brno Polytechnic. Representing the Jewish club of Maccabi Brno Kahane became a chess master of ÚJ̌̌̌ (i.e. the Main Society of Czecho-Slovakian Chess Players) in 19129 in Brno. In 1931 he was a chess master of Brno. After he had returned to Poland, Kahane became a member of the Chess Enthusiasts Association in Łódź. He took part in the Łódź Chess Competition $\left(4^{\text {th }}\right.$ place in $1932,3^{\text {rd }}$ place in 1934). He was also a member of the Łódź team in the Polish Chess Competition in 1934. In 1935, he emigrated to Romania, and later, in 1940, to Palestine (through Bulgaria and Turkey). In Israel, Kahane lived in Ramat Gan (Tel Aviv District) where he set up a chemical factory. He was the director of the company. Whether he played chess in Israel remains unknown. It is also unknown when he died.
\end{abstract}

